\title{
Educational Assortative Mating and Income Dynamics in Couples: A Longitudinal Dyadic Perspective
}

\author{
Yue Qian \\ Department of Sociology \\ University of British Columbia \\ Email: yue.qian@ubc.ca
}

Address correspondence to Yue Qian, Department of Sociology, University of British Columbia, 6303 NW Marine Drive, Vancouver, BC Canada, V6T 1 Z1.

\section{Author Note}

This manuscript is a preprint. An updated version (available upon request) has been accepted for publication in the Journal of Marriage and Family. 
RUNNING HEADS: EDUCATIONAL PAIRING AND INCOME DYNAMICS IN COUPLES

Educational Assortative Mating and Income Dynamics in Couples:

A Longitudinal Dyadic Perspective 
Educational Pairing and Income Dynamics in Couples

\begin{abstract}
The gender-gap reversal in education could have far-reaching consequences for marriage and family lives. Using data from the National Longitudinal Survey of Youth 1979 and longitudinal multilevel dyad models, this study investigated how educational assortative mating shaped income dynamics in couples over the marital life course. Based on educational assortative mating, couples were grouped into three categories - educational hypergamy (wives less educated than their husbands), homogamy, and hypogamy (wives more educated than their husbands). Results showed that change in husbands' income with marital duration was similar across couples, whereas change in wives' income varied by educational assortative mating such that wives in educational hypogamy exhibited more positive change in income over the marital life course. The findings underscored the asymmetric nature of spousal influence and gender change in heterosexual marriages.
\end{abstract}

Keywords Marriage, Life Course, Educational Assortative Mating, Income Trajectory, Gender 
Educational Pairing and Income Dynamics in Couples

Women have made greater gains in educational attainment than men over the past few decades in the United States. Since 1982, the gender gap in college completion has reversed from favoring men to favoring women (Buchmann \& DiPrete, 2006). The reversal of the gender gap in education could have far-reaching consequences for marriage and family lives (DiPrete \& Buchmann, 2013). As one consequence of the gender-gap reversal in education, profound changes in educational assortative mating - trends toward decreased educational hypergamy (wives less educated than their husbands) and increased educational hypogamy (wives more educated than their husbands) - have recently received much scholarly and media attention (e.g., Esteve, García-Román, \& Permanyer, 2012; Esteve et al., 2016; Qian, 2017; Schwartz \& Han, 2014; Wang, 2014). What are the implications of the decline in traditional educational hypergamy and increase in educational hypogamy for economic gender inequality in marriage? To answer this question, the current study used data from the National Longitudinal Survey of Youth 1979 (NLSY79) and multilevel dyad models (Lyons \& Sayer, 2005) to examine how educational assortative mating shaped income dynamics in couples over the course of marriage.

Research on income dynamics in couples is key to a full understanding of economic gender inequality within families. The resources one partner brings to the family affect the marital power one can exert (Blood \& Wolfe, 1960); therefore, feminist scholars have long argued that women's lower income relative to that of their husbands contributes to women's subordinated status and lower bargaining power in the family (England, 2003). By examining how educational assortative mating shapes husbands' and wives' long-term income trajectories, this study sheds light on the extent to which changes in gender equality in public arenas, such as education, has spilled over into personal relationships and thus could potentially reshape gender relations and power dynamics among heterosexual couples. 
Educational Pairing and Income Dynamics in Couples

\section{THEORETICAL FRAMEWORK}

I draw on the life course perspective (Elder, 1975, 1998) to understand the relationship between educational assortative mating and income dynamics in couples. As longitudinal data become increasingly available, scholars have called for applications of the life course perspective to studying families over time (Bengtson \& Allen, 2009). This perspective highlights continuity and change in individuals' employment and family experiences over the life course and recognizes the heterogeneity in marital relationships, individual experiences, and income trajectories (Elder, 1975). A key principle of the life course perspective is that of linked lives, which implies that mutual influences are constantly at work so that one's life trajectory is shaped by significant others (Elder, 1998; Elder, Johnson, \& Crosnoe, 2003). The "linked lives" principle suggests that circumstances in one partner's life, such as employment and income, would have implications for the other partner's life. Because spouses share many life experiences (e.g., typically living in the same household, having and raising children together) and make joint labor supply decisions (Becker \& Moen, 1999; Cha, 2010), their income trajectories are likely correlated.

Additionally, the principle of linked lives suggests that how husbands' and wives' incomes evolve over the course of marriage depends on not only their own educational levels but also their education relative to that of their spouses. Socioeconomic changes in recent decades, including globalization, shifts to the knowledge-based economy, an emphasis on innovation and technology, and increased bifurcation of the U.S. labor market into "good jobs" and "bad jobs," all mean that education has become an increasingly important indicator of earnings potentials and predictor of individuals' economic success (Autor, 2011; Blossfeld \& Buchholz, 2009; Fischer \& Hout, 2006; Goldin \& Katz, 2010). In addition, with increases in the prevalence of dual-earner couples, both spouses, especially wives, have become more likely to convert 
education into earnings (Blossfeld \& Buchholz, 2009; Raley, Mattingly, \& Bianchi, 2006). Thus, spouses' relative educational levels likely index their relative earnings capabilities, influence how couples divide their household and market labor, and in turn, shape both spouses' income trajectories over the course of marriage. The new home economics (Becker, 1981) posits that the sexual division of labor at home, with each spouse specializing in the sector he or she has a comparative advantage in, maximizes the household utility. Historically, husbands tended to have more education and invest more in human capital than did wives. Accordingly, husbands usually occupied the breadwinning role in the family, whereas wives specialized in the private sphere, rearing children and taking care of the home. It is possible that women's higher educational levels relative to their husbands could increase their ability to allocate time and energy to market work, especially during the periods in which education has been increasingly tied to occupational success (Fischer \& Hout, 2006). Taken together, as an indicator of their comparative advantage in market activities, married people's education relative to that of their spouses may very well shape their long-term income trajectories over the course of marriage.

In short, guided by the life course perspective, the current study empirically modeled the dynamic trajectories of husbands' and wives' incomes over the course of marriage. Recognizing the heterogeneity in income trajectories and the linked lives of couples, this study examined how educational assortative mating, that is, the educational pairing of spouses at marriage, played a role in shaping the long-term changes in husbands' and wives' incomes. Moreover, the principle of linked lives also implies that the husband's income trajectory may not be independent from that of the wife. Thus, using well-suited statistical models, this study not only took into account but also explicitly quantified the correlation between husbands' and wives' initial incomes at marriage as well as the correlation between spouses' rates of change in income. 
Educational Pairing and Income Dynamics in Couples

\section{Previous ReseARCH ON INCOME DyNAMICS In COUPLES AND THE CURRENT STUDY}

Female labor force participation has increased and the gender pay gap has narrowed considerably over the past few decades (Blau \& Kahn, 2000; England, 2010). In light of these changes in the labor market, the majority of married couples are now dual-earner couples (Raley et al., 2006). In addition, evidence from repeated cross-sectional data reveals that the share of couples in which wives are primary earners and positive associations between spouses' incomes have increased in recent decades (Cancian \& Reed, 1999; Raley et al., 2006; Schwartz, 2010).

Yet, our understanding of spouses' income changes over the marital life course remains incomplete. In fact, existing research that has examined the gender income gap within couples points to the importance of a longitudinal approach to capturing the dynamic nature of spouses' income trajectories. Two studies (Winkler, McBride, \& Andrews, 2005; Winslow-Bowe, 2006) examined the nontraditional arrangement where wives outearned their husband for three or five years and found that wives' income advantage was hardly persistent: although about 10 percent of wives earned 60 percent or more of couple's total income at a given year, less than half of them did so for 3 consecutive years, and only a quarter of them did so over a 5-year period.

While these two studies are important for highlighting the fleeting nature of wives' income advantage over their husbands, they are limited in two major ways. First, they did not fully reveal change over the marital life course. Their analyses of wives' income advantage were restricted to short time windows (three or five years). As work and family experiences change over the life course (Garcia-Manglano, 2015; Umberson, Pudrovska, \& Reczek, 2010), it is worth investigating how the dynamics of couples' income patterns evolve over a longer time frame. Additionally, both studies (Winkler et al., 2005; Winslow-Bowe, 2006) pooled couples at 
various durations of marriage. Thus, it is less clear how couples start off and how incomes of both spouses evolve from the first year of marriage over an extended period of time.

Second, while both studies (Winkler et al., 2005; Winslow-Bowe, 2006) examined wives' relative income, the question remains as to how gender differences in income trajectories contribute to declines in wives' income share. It is possible that income increases after marriage for both spouses, but husbands' income grows at a faster rate. Consequently, a decline in wives' relative income is largely due to husbands' faster rate of income growth. Alternatively, husbands' and wives' income trajectories may diverge after marriage, with increases in husbands' income but decreases in wives' income, which leads to a reduction in wives' economic contribution to the family. Indeed, prior research examined gender-specific income trajectories during marriage, but change in income with marital duration was often analyzed separately by gender based on nonpartnered data (e.g., Cheng, 2016; Cooke et al., 2009; Dougherty, 2006; Light, 2004). This line of research neglected the interdependence of couple members' behavior and experiences, such as shared characteristics and life events, associations between spouses' income, and the effects of spouses on one another's labor supply and income. Integrating and extending prior research, I used a nationally representative sample of the late baby boomer cohort from the NLSY79 and multilevel dyad models to investigate changes in husbands' and wives' incomes over the marital life course. Applying multilevel models to longitudinal dyadic data allowed me to take couples' interdependence into account, directly compare the husband's and wife's income trajectories, and assess heterogeneity in income changes across couples. In addition, I examined how and why educational assortative mating shaped the long-term patterns of spouses' income trajectories, which sheds light on the implications of women's rise in education for economic gender inequality within couples. 
Educational Pairing and Income Dynamics in Couples

\section{HYPOTHESES}

Despite women's progress in education and employment, by 2001, about two thirds of married couples were traditional couples in which the husband contributed 60 percent or more of the couple's income (Raley et al., 2006). In 1999, working wives, on average, produced less than one-third of total family income (Nock, 2001). In addition to the within-couple income gap observed at one point in time, over the family life course, married couples usually make family decisions that prioritize husbands' careers (Becker \& Moen, 1999). For example, women usually reduce their employment hours after childbirth, which contributes to the reduction in wives' relative earnings in households with young children (Winslow-Bowe, 2006, 2009). Migration also leads to a widening intrafamily gender earnings gap (Cooke et al., 2009). Given that gendered career prioritization evolves over time, marital duration was found to be negatively associated with the odds of wives' persistent income advantage (Winslow-Bowe, 2006).

Couples' decisions and earnings patterns within marriages may be influenced by labor market constraints. Research consistently reveals a "marriage premium” for men's wages, although it is still under lively debate whether this is attributed to selectivity into marriage, within-household specialization, increased productivities, or cultural beliefs of breadwinners attached to married men's marital role (e.g., Cheng, 2016; Chun \& Lee, 2001; Cohen, 2002; Cornwell \& Rupert, 1997; Dougherty, 2006; Killewald \& Gough, 2013; Light, 2004; Orloff, 1996). By contrast, findings regarding the effect of marriage on women's earnings are mixed (see Dougherty, 2006 for a review; also see Cheng, 2016; Killewald \& Gough, 2013). While the marriage premium for women is limited (if any), evidence of the motherhood penalty is clear (Budig \& England, 2001). After controlling for a series of factors such as human capital, labor supply, and characteristics of the jobs, employed mothers on average suffer a wage penalty 
Educational Pairing and Income Dynamics in Couples

(Budig \& England, 2001; England et al., 2016), whereas fathers, in particular married residential fathers, experience a wage premium (Glauber, 2008; Hodges \& Budig, 2010; Killewald, 2013). Therefore, it is likely that wives suffer a wage penalty whereas husbands experience a wage premium, especially if they are parents of minor children.

In sum, income dynamics in couples result from a complex interplay of couples' workfamily decisions and labor market constraints. In this study, I did not attempt to disentangle the effects of family processes and labor market forces. Rather, I aim to take an important initial step to examine the net effects of those mechanisms on husbands' and wives' income trajectories. Given family decisions that tend to prioritize husbands' careers and labor market rewards attached to married men and fatherhood, I hypothesize that 1) husbands and wives significantly differ in income trajectories in which on average, husbands' income increases over the marital life course whereas wives' income decreases at least in the early years of marriage.

The life course perspective emphasizes heterogeneity in life experiences, outcomes, and trajectories, suggesting that husbands' and wives' income trajectories likely vary across couples. Gary Becker's (1981) new home economics predicts an efficient sexual division of labor at home based on each spouse's comparative advantage. Thus, the more the husband and the wife resemble each other with respect to education and earnings potential at the time of marriage, the more slowly the wife's income may lag behind that of the husband following marriage. Empirical evidence shows that human capital does shape couples' earnings patterns. Women's education encourages their employment (England, Garcia-Beaulieu, \& Ross, 2004). If wives have invested in human capital more than their husbands, such as in marriages where wives have higher educational levels than their husbands, women are more likely to outearn their husbands in a single year and for several consecutive years (Raley et al., 2006; Winkler et al., 2005; 
Educational Pairing and Income Dynamics in Couples

Winslow-Bowe, 2006). Nevertheless, I suspect that how income trajectories vary by educational assortative mating likely differs between husbands and wives. Prior research revealed that men's employment was more likely than that of women to be affected by their spouses' attributes. For example, when investigating the effect of spousal overwork on one's own employment among dual-earner couples, Cha (2010) found gender-asymmetric effects: having a spouse who worked long hours significantly increased women's but not men's likelihood of quitting a job. Relatedly, in examining husbands' and wives' work responses to parenthood, Killewald and GarcíaManglano (2016) found variation in wives' adjustments but little change in husbands' work behaviors following the transition to fatherhood. Taken together, I hypothesize that 2) wives ' income trajectories depend on educational assorative mating to a greater extent than husbands' income trajectories, with decreases in wives' income over the course of marriage being less pronounced among hypogamous couples (wife more educated than husband) than among homogamous or hypergamous couples (wife's education equal to or surpassing that of the husband). Furthermore, given the central role of parenthood and employment in shaping earnings, in particular for women, I hypothesize that 3) childbearing and employment behaviors are contributing factors of wives' variation in income trajectory by educational assortative mating.

\section{METHOD}

Data

I used 25 waves of data from the National Longitudinal Survey of Youth 1979 (NLSY79) to examine how husbands' and wives' incomes jointly evolved over the marital life course. The NLSY79 is a nationally representative sample of 12,686 people aged 14-22 years at the time of their first interviews in 1979. The survey was conducted annually through 1994 and is currently 
Educational Pairing and Income Dynamics in Couples

carried out biennially, thereby having followed a large sample of the late baby boomer cohort born between 1957 and 1964 who received education, entered the labor force, and formed marriages during the period when the most rapid changes in women's economic and family roles occurred (Goldin, 2004). When the cohort was first surveyed, nearly $90 \%$ of the respondents $(11,117$ out of 12,686$)$ were never married, which made it possible to track the vast majority of the respondents from the beginning of their first marriages. At the time of their 2012 interviews (the most recent data available at the time of this research), the respondents were 47-56 years of age and approaching the end of their prime working-age years. Thus, the NLSY79 provides a unique opportunity to study income dynamics in couples among the late baby boomer cohort over almost the entire marital life course during which both partners were of active working age.

\section{Sample}

I restricted my analysis to 9,763 respondents who were followed throughout the entire survey period, including a representative sample of the U.S. noninstitutionalized civilian population aged 14 to 22 years in $1979(N=6,111$,$) and a supplementary sample of Hispanics and blacks (N$ $=3,652)$. I then dropped 1,885 respondents who had never been married since they were first interviewed. Additionally, I excluded 215 respondents with missing data on year of their first marriage because the timing and duration of these marriages could not be accurately determined. The 7,663 individuals left in the sample had a total of 173,148 person years. Income dynamics in couples may vary by marriage order, but the small number of higher-order marriages makes it difficult to produce robust results given that modeling multiple marriages for respondents, if they occur, requires three-level hierarchical models. Therefore, I limited the sample to 72,461 person years for which the NLSY79 respondents were in their first marriages with spouse present. 
Educational Pairing and Income Dynamics in Couples

I further refined the sample based on key variables of interest. Given the interest in the effect of educational assortative mating (i.e., the educational pairing of spouses at the time of marriage), I needed to identify both spouses' education at marriage. I imputed missing data on educational levels at marriage using the value reported in the survey year closest to the year of marriage, provided that it was within the first three years of marriage (Killewald \& Gough, 2013). Respondents' entire person-years were dropped if either their own or their spouses' education at marriage was missing after imputation. 69,268 person years were left. Because of the focus on income dynamics in couples, I restricted the analytic sample to 66,490 person years in marriage during which both spouses were of working age (18-55 years) when their incomes were measured. I excluded 6,824 person years that represented marital lives after more than twenty years of marriage (ranging between 21 and 36 years) because these person-year data were sparse and selective (Cheng, 2016). 59,666 person years were left in the sample.

The NLSY79 contains information on income, age, education, and labor supply of respondents and proxy data on spousal characteristics. I converted the 59,666 person years into the person years of husbands and those of wives to use multilevel dyad models. The person years of husbands were based on either interviews of male respondents or female respondents' reports of spousal information, and the person years of wives were likewise obtained. After I dropped the person years with missing data on variables used in the analysis, the final sample included 53,038 person years of husbands and 53,675 person years of wives. The number of husbands' and wives' person years differed because missing data might exist for one spouse but not for the other. Multilevel dyad models are well-suited to accommodate such unbalanced data structure. 
Educational Pairing and Income Dynamics in Couples

\section{Measurement}

\section{Dependent Variable}

Following prior research on wives' income advantage (Winslow-Bowe, 2006), I defined husbands' (wives') income as their annual wage and salary earnings. In fact, individuals' wage and salary income, on average, constitutes more than $90 \%$ of their total income from all sources (Qian, 2017; Schwartz, 2010). I adjusted incomes to 2012 dollars using the CPI-U-RS from 1947 to 2013 (Schwartz, 2010). To avoid extreme values, I recoded incomes above the 99th or below the 1 st percentiles of the weighted distribution to the 99th and 1st percentiles, respectively (Killewald \& Gough, 2013). As is commonly done in research, I took the natural log of income to correct for right skewness, and before doing so, I added a constant of one to each income to handle zero values. Note that the results presented below were robust to alternative specifications, such as the inverse hyperbolic sine transformation (Friedline, Masa, \& Chowa, 2015).

\section{Independent Variables}

One main independent variable is a time-varying variable-years since marriage (i.e., marital duration), defined as the year in which income was measured minus the year of marriage. I added both marital duration and its squared term to capture the non-linear change in income over the course of marriage. The other independent variables are two sets of time-invariant, educationrelated variables measured roughly at the time of marriage: 1) individuals' own educational levels - less than high school, high school diploma (reference category), some college, and college degree or above, and 2) educational assortative mating reflecting spouses' relative educational levels - educational hypergamy (husband's educational level higher than that of wife), educational homogamy (husband's educational level equal to that of wife; reference 
Educational Pairing and Income Dynamics in Couples

category), and educational hypogamy (husband's educational level lower than that of wife). Such operationalization of the education-related variables was adopted by prior studies on the gendergap reversal in education and family outcomes (Esteve et al., 2016; Schwartz \& Han, 2014).

\section{Time-Varying Covariates}

Hypothesis 3 proposes childbearing and employment as contributing factors of variation in income trajectories by educational assortative mating. I measured husband's and wife's labor supply as a time-varying variable, using the number of hours that each spouse worked during the year when the income was measured. The results below based on annual work hours were robust to alternative employment measures, such as annual weeks worked or usual weekly hours.

To measure fertility, I created a time-varying, continuous variable for number of children, base on fertility history data in the NLSY79 that included the birth year of every child born to the NLSY79 respondents and dates of death for children who had died. I defined number of children as the number of surviving biological children (of the NLSY79 respondents) under the age of 18 years, regardless of whether the child was living in the household or not (Killewald \& Gough, 2013). Parental status was considered as a shared trait of two spouses, so number of children constructed from the NLSY79 respondents' fertility history was also applied to their spouses.

\section{Time-Invariant Covariates}

Time-invariant control variables included age at marriage, race, and whether the respondent was the husband or the wife. I controlled for husband's (wife's) age at marriage, because marriage timing (i.e., when individuals entered marriage) was found to be related to individuals' own educational levels, educational assortative mating, as well as individuals' career development 
Educational Pairing and Income Dynamics in Couples

and income trajectories (Dahl, 2010; Mare, 1991; Oppenheimer, Kalmijn, \& Lim, 1997;

Sweeney, 2016). Race needs to be included because the long-term wage effect of marriage and educational assortative mating patterns tend to vary by race (Cheng, 2016; Qian, 1997).

Unfortunately, because the NLSY79 only collected information on race of respondents' spouses at the 2008 and 2012 interviews, respondents who were not interviewed in these two waves had missing data on their spouses' race. Given the relatively small percentage of interracial marriages, I included only respondents' own race in the analysis, measured through three categories:

Hispanic, black, and non-black, non-Hispanic (referred to as white thereafter; reference category). As mentioned earlier, spousal information was proxy data obtained from the respondents. Whether the couple member was the respondent or not may affect the information precision, so I included a variable indicating whether the respondent was the husband $(=0)$ or the wife $(=1)$.

\section{Analytic Strategies}

I used multilevel dyad models that essentially extend growth curve modeling to the dyadic context (Keizer \& Schenk, 2012; Lyons \& Sayer, 2005; Raudenbush, Brennan, \& Barnett, 1995). Although marital timing differed across individuals, marital duration varied across couples, and the frequency of the NLSY79 has changed from annual to biennial since 1994, multilevel dyad models are well-suited for dealing with the situations in which both the number of observations and the timing of observations vary over participants. Moreover, multilevel dyad models can simultaneously estimate the income trajectory of the husband and that of the wife, which has several advantages compared with when trajectories of the husband and the wife are estimated in separate models. First, multilevel dyad models estimate a unique trajectory for each spouse, and allow the incongruence of the average trajectories for each spouse to be formally tested for 
Educational Pairing and Income Dynamics in Couples

significant differences at the intercept, the slope, or both. Second, multilevel dyad models control for autocorrelation among the repeated measures and adjust the error variance for the interdependence of spousal outcomes within the same couple (Lyons \& Sayer, 2005). Third, although there are missing responses where some couples may have only one spouse's data, multilevel dyad models can handle this type of unbalanced data.

\section{Level-1 Model: Within-Dyad Model}

$$
\begin{aligned}
Y_{\text {it }}= & (\text { husband })\left[\beta_{1 \mathrm{i}}+\beta_{2 \mathrm{i}}\left(\text { linear }_{i t}\right)+\beta_{3 \mathrm{i}}\left(\text { quadratic }_{i t}\right)\right] \\
& +(\text { wife })\left[\beta_{4 \mathrm{i}}+\beta_{5 \mathrm{i}}\left(\text { linear }_{i t}\right)+\beta_{6 \mathrm{i}}\left(\text { quadratic }_{i t}\right)\right]+e_{\mathrm{it}},
\end{aligned}
$$

where $Y_{\text {it }}$ represents logged income with $t=1, . . \mathrm{K}$ responses for dyad (i.e., couple) $i$. The model consists of intercepts as well as linear and quadratic slopes for husbands and wives, separately. The intercepts $\beta_{1 \mathrm{i}}$ and $\beta_{4 \mathrm{i}}$ denote expected logged income at the start of marriage for the husband and wife within couple $i$, respectively. When income is logged and a quadratic slope is included, the linear slope, for example $\beta_{2 \mathrm{i}}$, means that the instantaneous rate of change in the husband's income at the time of marriage is $\left(100 \times \beta_{2 \mathrm{i}}\right) \%$ (Singer \& Willett, 2003; Stock \& Watson, 2006).

\section{Unconditional Level-2 Model: Between-Dyad Model}

At Level 2, each estimated parameter (e.g., intercept, linear slope, or quadratic slope) consists of an estimated population average over dyads and a random effect per dyad. In the unconditional model without any covariates at Level 2, these parameters can be written as

$$
\beta_{\mathrm{si}}=\gamma_{s}+u_{s i}
$$

where $\beta_{\text {si }}$ represents the estimated parameter $s(s=1,2,3,4,5,6)$ for dyad $i$, with $\gamma$ denoting the estimated population average and $u$ denoting the random effect for parameter $s$ of dyad $i$. 
Educational Pairing and Income Dynamics in Couples

\section{Conditional Level-2 Model: Between-Dyad Model}

To examine heterogeneity in husbands' and wives' income trajectories across dyads, I included individuals' own educational levels (HEDU = husbands' education; WEDU = wives' education) and their education relative to that of their spouses indexed by RELEDU in conditional models.

$$
\begin{aligned}
& \beta_{1 \mathrm{i}}=\gamma_{10}+\gamma_{11} \mathrm{HEDU}+\gamma_{12} \mathrm{RELEDU}+u_{1 \mathrm{i}} \\
& \beta_{2 \mathrm{i}}=\gamma_{20}+\gamma_{21} \mathrm{HEDU}+\gamma_{22} \mathrm{RELEDU}+u_{2 \mathrm{i}} \\
& \beta_{3 \mathrm{i}}=\gamma_{30}+\gamma_{31} \mathrm{HEDU}+\gamma_{32} \mathrm{RELEDU}+u_{3 \mathrm{i}} \\
& \beta_{4 \mathrm{i}}=\gamma_{40}+\gamma_{41} \mathrm{WEDU}+\gamma_{42} \mathrm{RELEDU}+u_{4 \mathrm{i}} \\
& \beta_{5 \mathrm{i}}=\gamma_{50}+\gamma_{51} \mathrm{WEDU}+\gamma_{52} \mathrm{RELEDU}+u_{5 \mathrm{i}} \\
& \beta_{6 \mathrm{i}}=\gamma_{60}+\gamma_{61} \mathrm{WEDU}+\gamma_{62} \mathrm{RELEDU}+u_{6 \mathrm{i}}
\end{aligned}
$$

\section{Conditional Level-1 and Level-2 Models}

Finally, I estimated a full model by adding all time-varying covariates to the level-1 model and time-invariant covariates to the level-2 models. To facilitate interpretation (Singer \& Willett, 2003), I centered age at marriage at 24 years. In addition, I centered annual work hours by subtracting 1,750 $(=35 \times 50)$ from hours worked during the year at each spouse's person year; this strategy captured deviation from the minimum work hours of full-time, year round workers (i.e, those working 35 or more hours per week and 50 or more weeks per year; Bianchi, 2000).

\section{RESULTS}

\section{Descriptive Results}

Table 1 presents the descriptive statistics of the time-invariant variables (upper panel) and time varying-variables (lower panel), for husbands and wives, respectively. About 23 percent of the 
Educational Pairing and Income Dynamics in Couples

husbands and wives were in traditional educational hypergamy (husband more educated than wife), 53 percent of them were in educational homogamy, and 24 percent of them were in educational hypogamy (wife more educated than husband). At the time of marriage, 18, 43, 20, and 19 percent of the husbands had less than a high school education, a high school diploma, some college education, and a college degree or above, respectively. The respective figures for the wives were $15,44,23$, and 18 percent. The mean age at marriage was about 26 years for the husbands and 24 years for the wives. In both the husband sample and the wife sample, 19, 23, and 58 percent of the NLSY79 respondents were Hispanics, blacks, and whites, respectively, and about 52 percent of the NLSY79 respondents were wives.

Time-varying variables were measured at the person-year level. The mean of the dependent variable_-logged income — was 10 for husbands and 7.4 for wives across their personyear observations. Marital duration (i.e., years since marriage) ranged from 0 to 20, with a mean

of roughly seven years for both spouses. The number of children ranged from zero to nine, with a mean of 1.4 across person-year observations for both husbands and wives. Hours worked during the year averaged 2,150 and 1,260 hours across husbands' and wives' person years, respectively.

\section{[TABLE 1 INSERTED ABOUT HERE]}

\section{Baseline Model Results}

Next, I discuss results of multilevel dyad models. I first estimated the baseline model (Model 1) that included intercept as well as linear and quadratic slopes at Level 1 separately for husbands and wives (specified as Equation (1)) and allowed the intercepts and slopes to vary across couples (specified as Equation (2)). The fixed effects and random effects in Model 1 are presented in Table 2. The fixed effects provide the model-estimated average curves for husbands 
Educational Pairing and Income Dynamics in Couples

and wives. To facilitate interpretation of the fixed effects, the trajectories of husbands' and wives' incomes (in dollars) are plotted in Figure 1. As shown in Figure 1, husbands on average had higher income than wives at the time of marriage. In terms of change over time, wives' income declined in the early years of marriage, and the rate of decline in wives' income decreased over the course of marriage. After about eight years of marriage, wives' income increased with every additional year of marital duration. Husbands' income increased rapidly in the early years of marriage, although the rate of increase in husbands' income appeared to decrease over time. Husbands' income, nevertheless, increased with marital duration in the first twenty years of marriage. Post-estimation tests confirmed that husbands and wives followed different average income trajectories over the marital life course, because the differences in the intercept, the linear trend, and the quadratic effect between wives and husbands were all significant at the 0.001 level.

\section{[TABLE 2 \& FIGURE 1 INSERTED ABOUT HERE]}

Note that Figure 1 presents a simplified summary of Model 1 because this figure does not take into account the random components (i.e., variance and covariance components). The actual level of initial income at the time of marriage and how income actually changed within marriage depend on the variance components. The variance components for the baseline model in Table 2 indicate considerable variation in the intercepts as well as the linear and quadratic slopes across couples. For example, linear slopes varied between -0.101 and 0.189 (i.e., $0.044 \pm 1.96 \times 0.074$ ) for 95 percent of husbands and between -0.749 and 0.361 (i.e., $-0.194 \pm 1.96 \times 0.283$ ) for 95 percent of wives. Notably, wives were more variable than husbands in their income trajectories, at least in terms of income at the time of marriage and the instantaneous rate of change in income following marriage (compare standard deviation of 3.430 and 1.688 for the intercept and standard deviation of 0.283 and 0.074 for the linear slope, for wives and husbands, respectively). 
Educational Pairing and Income Dynamics in Couples

In addition, the matrix of correlations among the level-2 random effects in Table 2 reveals shared variances in the outcomes for members of the couple. Specifically, the random effects of intercepts and linear slopes of husbands and wives were correlated: high-earning men and women tended to marry each other (correlation $=0.346)$ and one spouse's change in income after marriage was slightly positively related to that of the other spouse (correlation $=0.043$ ). The initial income at marriage and change in income following marriage were not independent between two spouses, which gives evidence for the "linked lives" perspective and highlights the importance of taking into account the interdependence of spouses' income trajectories.

To sum up, the baseline model produced several major findings. First, according to the fixed effects results, the average curves, in terms of income at the time of marriage and change in income with marital duration, significantly differed between husbands and wives. Second, results of the variance components indicated there was substantial variation across couples in income trajectories and that variation in income trajectories appeared to be more pronounced among wives than among husbands. Third, the matrix of correlations revealed that spouses' initial incomes at the time of marriage and rates of change in income were both positively correlated.

\section{Variation in Husbands' and Wives' Income Trajectories by Educational Assortative Mating}

Next, in Model 2, I included educational assortative mating and individuals' own educational attainment at the time of marriage at level-2 models (specified as Equations (3) through (8)). The results illustrate how husbands' and wives' income trajectories, in terms of the intercepts, the linear slopes, and the quadratic terms, varied by their own education and their education relative to that of their spouses. The results for the fixed effects are presented in Model 2 of Table 3. An interesting gender difference arises. For wives, both their own education and their education 
Educational Pairing and Income Dynamics in Couples

relative to that of their husbands were significantly related to their income trajectories. Wives' own education was positively associated with their income at the start of marriage. Controlling for wives' own education, compared with wives in educational homogamy, wives in hypergamy (husband more educated than wife) had higher income at the time of marriage $(b=0.430, p<$ $0.01)$ but a more negative linear slope $(b=-0.067, p<0.01)$, while wives in hypogamy (wife more educated than husband) had lower initial income $(b=-0.544, p<0.001)$ but a more positive linear slope $(b=0.186, p<0.001)$. In contrast, for husbands, there were much fewer significant effects. In fact, none of the variables indicating educational assortative mating were significant in predicting husbands' linear or quadratic slope.

\section{[TABLE 3 \& FIGURE 2 INSERTED ABOUT HERE]}

To facilitate comparisons of the variation in husbands' and wives' income trajectories by educational assortative mating, I present the predicted income in dollars for husbands and wives, respectively, in Figure 2. To illustrate how income trajectories varied across educational pairings of spouses net of the effect of individuals' own education, I set husbands' and wives' own education at marriage as the reference category (i.e., a high school diploma). Controlling for husbands' own education, husbands in hypergamy (husband more educated than wife) had significantly lower income at the start of marriage than husbands in homogamy or hypogamy (wife more educated than husband), but change in husbands' income with marital duration was very comparable across three types of couples. Regardless of educational assortative mating, husbands' income increased at a decreasing rate over the first twenty years of marriage.

Controlling for wives' own educational levels, at the start of marriage, wives in hypergamy (husband more educated than wife) had the highest income, wives in hypogamy (wife more educated than husband) had the lowest income, and wives in educational homogamy 
Educational Pairing and Income Dynamics in Couples

fell between the two groups. Recall that variation in husbands' income at marriage by educational assortative mating exhibited the reverse pattern. Combined, these results were consistent with prior findings showing that men and women with lower earnings were more likely to marry less-educated spouses than themselves (Dribe \& Nystedt, 2013).

Although wives in hypogamy had the lowest income at the onset of marriage, their income only slightly declined in the early years of marriage and then gradually increased. In contrast, income declined more rapidly in the early years of marriage for wives in homogamy and the decline in income was even more pronounced for wives in traditional educational hypergamy. After about the first five years of marriage, the ranking of the average income earned by the three groups of wives reversed: wives in hypogamy had the highest income, whereas wives in hypergamy had the lowest income. Overall, Figure 2 clearly shows that husbands' income at the start of marriage varied by educational assortative mating, but how husbands' income changed after marriage did not vary much. For wives, both their income at the time of marriage and change in income after marriage varied by educational assortative mating.

\section{Full Model Including All Covariates}

In Model 3 of Table 3, I included all the covariates, with the time-varying variables (number of children and annual work hours) included at Level 1 and the time-invariant variables (age at marriage, which spouse was the respondent, and respondent's race) at Level 2. Similar to the results in Model 2, the variables measuring educational assortative mating were not significant in predicting husbands' linear or quadratic slope in Model 3. Thus, I focus on describing the results for wives. Differences in the coefficients for hypergamy and hypogamy between Models 2 and 3 suggest that after controlling for other covariates, 1) income at the time of marriage and the 
Educational Pairing and Income Dynamics in Couples

linear change in income no longer differed between wives in hypergamy (husband more educated than wife) and wives in homogamy, and 2) though still significant, the linear and quadratic terms for wives in hypogamy (wife more educated than husband) became much attenuated. In supplementary analyses, I added the time-invariant and time-varying variables separately, and found that change in the coefficients for educational assortative mating from Model 2 to Model 3 among wives was mainly driven by adding the time-varying variables. Compared with wives in educational homogamy, wives in hypergamy on average had slightly more children (1.42 versus 1.40$)$ and worked fewer hours during the year $(1,117$ versus 1,245$)$, whereas wives in hypogamy had fewer children (1.34 versus 1.40) and greater annual work hours $(1,428$ versus 1,245$)$. Because number of children was negatively associated with wives' income and annual work hours were positively related to wives' income $\left(b_{\text {Number }}\right.$ of children $=-0.235, p<$ $0.001 ; b_{\text {Hours worked during the year }}=0.003, p<0.001$; see Model 3$)$, these two variables accounted for the more pronounced drop in income over the marital life course for wives in hypergamy and explained much of the more positive change in income during marriage for wives in hypogamy.

\section{Sensitivity Analyses}

I conducted a series of sensitivity analyses (all available upon request) to test the robustness of the results. First, although in some marriages at least one spouse experienced educational upgrades, in this paper, I treated education as a time-invariant variable, instead of a time-varying variable. Conceptually, it was well-suited to use education at the time of marriage in the analysis to investigate how spouses' education at the start of marriage set stages for income dynamics in couples later on. Empirically, the NLSY79 asked incomes earned prior to the survey year but education at the time of the interview. In addition, the frequency of the NLSY79 has changed 
Educational Pairing and Income Dynamics in Couples

from annual to bi-annual since 1994. Thus, the survey design made it very difficult, if possible, to accurately link contemporaneous or prior status on the education-related predictors with current status on the income outcome. As a robustness check, I restricted the analysis to those married at age 24 or older (traditional standard post-college ages) and results did not change.

Second, similar to previous related research (Esteve et al., 2016; Schwartz \& Han, 2014), after controlling for individuals' own educational levels, I measured educational assortative mating by using educational hypergamy, homogamy, and hypogamy. I also ran sensitivity analysis to include both spouses' educational levels (six variables) and full interaction terms between spouses' education (nice variables). The analysis produced substantively the same results as I present above: for example, among wives with some college education, compared with those married to husbands with some college education (homogamy), the initial logged income at marriage was 0.779-point lower, 0.147-point lower, and 0.230-point higher for those married to high school dropouts (hypogamy), those married to high school graduates (hypogamy), and those married to college graduates (hypergamy), respectively, and the respective figures for the linear slope were 0.078-point higher, 0.045-point higher, and 0.135point lower. I did not adopt the more detailed specification of the education-related variables because it rendered results much less straightforward to interpret. In addition, some educational pairings had very small sample sizes. For instance, less than ten couples involved husbands with a college degree or above and wives with less than a high school education.

Third, the number of person years can vary over participants in multilevel dyad models, but this is free from selection bias only when such variation is random across persons (Raudenbush et al., 1995). In my case, however, attrition due to divorce may not be random (Kalmijn, Loeve, \& Manting, 2007). For example, if nonnormative marriages in which wives 
Educational Pairing and Income Dynamics in Couples

have more education and higher income than their husbands are more likely to dissolve, selection out of marriage due to divorce likely underestimates the positive rate of change in wives' incomes over the course of marriage. As a robustness check, I refit the same models using two alternative samples that capture spouses' income trajectories among couples who remained married: 1) respondents whose first marriage never ended and their first spouses $(N=35,968$ person years of husbands \& 36,290 person years of wives), and 2) respondents whose first marriage lasted twenty years or longer and their first spouses $(N=33,942$ person years of husbands \& 34,243 person years of wives). The results based on intact first marriages or first marriages lasting for at least twenty years were similar to those based on all first marriages: how husbands' income changed with marital duration was not associated with educational assortative mating, whereas wives' income trajectories varied by educational assortative mating and such variation was largely explained by wives' parenthood and labor supply characteristics. Couples who remained married analyzed in this sensitivity analysis represented the most restrictive sample, whereas all first marriages examined in the main analysis comprised the most inclusive sample. I leave the task of fully exploring how selection out of marriage might affect variation in spouses' income trajectories to future research, but clearly, the results of the current study held across samples at the two extreme ends, indicating the robustness of the findings.

\section{SUMMARY AND DISCUSSION}

The decline and eventual reversal of the gender gap in education could potentially have farreaching consequences for marriage and family lives (DiPrete \& Buchmann, 2013; Esteve et al., 2012, 2016). One consequence is the growing number of marriages in which wives are more educated than their husbands (i.e., educational hypogamy; Esteve et al., 2012, 2016; Qian, 2017; 
Educational Pairing and Income Dynamics in Couples

Schwartz \& Han, 2014). What are the implications of increases in educational hypogamy for economic gender inequality in heterosexual marriages? To answer this question, this study used data from the NLSY79 and multilevel dyad models to track income dynamics in couples over the first twenty years of marriage and to investigate how educational assortative mating shaped the economic positions of both spouses over the marital life course. It produced several key findings.

Consistent Hypothesis 1, the baseline model (Model 1) indicated that the average income curves significantly differed between husbands and wives: husbands' income increased over the first twenty years of marriage, whereas wives' income decreased in the early years before gradually increasing. Despite differences in the overall trajectory shape, results from the random components of the baseline model revealed that two spouses' income trajectories were linked. Adding to the literature on the association between spouses' earnings (Schwartz, 2010) or wage changes following parenthood (Killewald \& García-Manglano, 2016), this study found that highearning individuals tended to marry each other and one spouse's change in income over the course of marriage was positively related to that of the other spouse.

Were income dynamics in couples shaped by educational assortative mating? Consistent with Hypothesis 2 regarding gender-asymmetric effects of educational assortative mating on income trajectory, the conditional level-2 model (Model 2) showed that wives' but not husbands' income changes following marriage were significantly related to educational assortative mating. In addition, having more education than their husbands seemed to benefit women's long-term economic standing: despite initially being the lowest, income of wives in hypogamy caught up quickly because it only slightly declined within the first few years of marriage and then gradually increased; in contrast, for wives in homogamy and hypergamy, income declined more rapidly and for longer years in marriage. Taken together, these results highlight the importance of taking 
a life course approach to understand spouses' (in particular wives') economic standing because income trajectories are dynamic, heterogeneous, and linked with their significant others' lives.

Furthermore, by adding other covariates, I found that the more pronounced drop in income after marriage for wives in hypergamy (husband more educated than wife), compared with the drop in income for wives in educational homogamy, was primarily due to larger number of children they had and fewer hours they worked during the year, which provided supportive evidence for Hypothesis 3. Yet, the distinct income trajectories for wives in hypogamy (wife more educated than husband) cannot be fully explained by family size and annual work hours. Future research could investigate the role of other potential factors, such as work-family ideals, occupational characteristics, and gender divisions of household labor, in shaping income trajectories of wives in educational hypogamy. This is an important avenue for future research, as the female advantage in educational attainment and the corresponding number of educationally hypogamous couples have grown larger in more recent cohorts than in the NLSY79 cohort (Buchmann \& DiPrete, 2006; Schwartz \& Han, 2014; Qian, 2017). How women with an educational advantage over their husbands can maintain high earning capabilities following marriage could have profound implications for gender equality in American marriages. This study revealed asymmetric effects of educational assortative mating on husbands' and wives' income trajectories. Change in husbands' income with marital duration did not seem to vary by their education relative to that of their wives. In contrast, wives in hypogamy (wife more educated than husband) tended to have more positive change in income following marriage, compared with wives in other types of marriage. This adds to the existing literature showing that women's career decisions are sensitive to and even depend on their husbands' situations whereas men remain as more autonomous persons in marriage (Cha, 2010). Additionally, Winslow-Bowe 
(2006) found that women who had an educational advantage over their husbands were more likely to earn more than their husbands for 5 consecutive years. This study suggests that the higher likelihood of maintaining an income advantage for wives in hypogamy may be primarily because income for wives in this group does not drop dramatically after marriage, rather than because of differential changes in husbands' income by educational assortative mating.

The limitation of this study is that it mainly provided a description of husbands' and wives' income trajectories and their variation by educational assortative mating. It was less clear what drove the income trajectories. In other words, were change in income following marriage and variation in income change across couples due to differential bargaining power within the couple, different preferences for work-family arrangements, or institutional constraints (such as workplace policies and gender discrimination at work)? Clearly, all these processes were likely at work and couples' decisions and even preferences could be shaped by institutional constraints that they face in the workplace and the society at large (Becker \& Moen, 1999; England, 2016; Pedulla \& Thébaud, 2015). Future research could incorporate workplace characteristics of both spouses to better disentangle and quantify the contribution of individual-, couple-, and contextual-level factors in shaping economic gender inequality over the marital life course.

In sum, this study is unique in that it examined the relationship between educational assortative mating and income dynamics in couples from a dyadic and longitudinal perspective. The findings suggest that it remains important for husbands to bring income into the family regardless of their education relative to their wives, whereas the rise of women's education and the growing prevalence of marriages in which the wife is more educated than the husband likely protect women from earning less after getting married. Hence, this study underscores the asymmetry of gender change-women's lives have changed more than men's (England, 2010). 
Educational Pairing and Income Dynamics in Couples

\section{REFERENCES}

Autor, D. (2011). The polarization of job opportunities in the U.S. labor market: Implications for employment and earnings. Community Investments, 23, 11-16. http://www.frbsf.org/community-development/files/CI_IncomeInequality_Autor.pdf

Becker, G. S. (1981). A treatise on the family. Cambridge, MA: Harvard University Press.

Becker, P. E., \& Moen, P. (1999). Scaling back: Dual-earner couples’ work-family strategies. Journal of Marriage and the Family, 61, 995-1007.

Bengtson, V. L., \& Allen, K. R. (2009). The life course perspective applied to families over time. In P. Boss, W. J. Doherty, R. LaRossa, W. R. Schumm, \& S. K. Steinmetz (Eds.), Sourcebook of family theories and methods: A contextual approach (pp. 469-504). Springer.

Bianchi, S. M. (2000). Maternal employment and time with children: Dramatic change or surprising continuity? Demography, 37, 401-414.

Blau, F. D. \& Kahn, L. M. (2000). Gender differences in pay. Journal of Economic Perspectives, 14, 75-99.

Blossfeld, H. P., \& Buchholz, S. (2009). Increasing resource inequality among families in modern societies: The mechanisms of growing educational homogamy, changes in the division of work in the family and the decline of the male breadwinner model. Journal of Comparative Family Studies, 40, 603-616.

Buchmann, C., \& DiPrete, T. A. (2006). The growing female advantage in college completion: The role of family background and academic achievement. American Sociological Review, 71, 515-541.

Budig, M. J. \& England, P. (2001). The wage penalty for motherhood. American Sociological Review, 66, 204-225.

Cancian, M., \& Reed, D. (1999). The impact of wives' earnings on income inequality: Issues and estimates. Demography, 36, 173-184.

Cha, Y. (2010). Reinforcing separate spheres: The effect of spousal overwork on men's and women's employment in dual-earner households. American Sociological Review, 75, 303329.

Cheng, S. (2016). The accumulation of (dis) advantage: The intersection of gender and race in the long-term wage effect of marriage. American Sociological Review, 81, 29-56.

Chun, H., \& Lee, I. (2001). Why do married men earn more: Productivity or marriage selection? Economic Inquiry, 39, 307-319.

Cohen, P. N. (2002). Cohabitation and the declining marriage premium for men. Work and Occupations, 29, 346-363. 
Educational Pairing and Income Dynamics in Couples

Cooke, T. J., Boyle, P., Couch, K., \& Feijten, P. (2009). A longitudinal analysis of family migration and the gender gap in earnings in the United States and Great Britain. Demography, 46, 147-167.

Cornwell, C., \& Rupert, P. (1997). Unobservable individual effects, marriage and the earnings of young men. Economic Inquiry, 35, 285-294.

Dahl, G. B. (2010). Early teen marriage and future poverty. Demography, 47, 689-718.

DiPrete, Thomas A. \& Buchmann, Claudia. (2013). The rise of women: The growing gender gap in education and what it means for American schools. Russell Sage Foundation.

Dougherty, C. (2006). The marriage earnings premium as a distributed fixed effect. Journal of Human Resources, XLI, 433-443.

Dribe, M., \& Nystedt, P. (2013). Educational homogamy and gender-specific earnings: Sweden, 1990-2009. Demography, 50, 1197-1216.

Elder, G. H. (1975). Age differentiation and the life course. Annual Review of Sociology, 1, 165190.

Elder, G. H. (1998). The life course as developmental theory. Child Development, 69, 1-12.

Elder, G. H., Johnson, M. K., \& Crosnoe, R. (2003). The emergence and development of life course theory. In J. T. Motimer \& M. J. Schanahan (Eds.), Handbook of the life course (pp. 3-19). New York: Kluwer Academic/Plenum Publishers.

England, P. (2003). Separative and soluble selves: Dichotomous thinking in economics. In M. A. Ferber \& J. A. Nelson (Eds.), Feminist economics today-Beyond economic man (pp. 3359). Chicago, IL: The University of Chicago Press.

England, P. (2010). The gender revolution: Uneven and stalled. Gender \& Society, 24, 149-166.

England, P. (2016). Sometimes the social becomes personal: Gender, class, and sexualities. American Sociological Review, 81, 4-28.

England, P., Bearak, J., Budig, M. J., \& Hodges, M. J. (2016). Do highly paid, highly skilled women experience the largest motherhood penalty?. American Sociological Review, 81, 1161-1189.

England, P., Garcia-Beaulieu, C., \& Ross, M. (2004). Women's employment among blacks, whites, and three groups of Latinas: Do more privileged women have higher employment? Gender \& Society, 18, 494-509.

Esteve, A., García-Román, J., \& Permanyer, I. (2012). The gender-gap reversal in education and its effect on union formation: The end of hypergamy? Population and Development Review, 38, 535-546.

Esteve, A., Schwartz, C. R., Bavel, J., Permanyer, I., Klesment, M., \& García-Román, J. (2016). The end of hypergamy: Global trends and implications. Population and Development Review, 42, 615-625. 
Educational Pairing and Income Dynamics in Couples

Fischer, C. S., \& Hout, M. (2006). Century of difference: How America changed in the last one hundred years. Russell Sage Foundation.

Friedline, T., Masa, R. D., \& Chowa, G. A. (2015). Transforming wealth: Using the inverse hyperbolic sine (IHS) and splines to predict youth's math achievement. Social Science Research, 49, 264-287.

García-Manglano, J. (2015). Opting out and leaning in: The life course employment profiles of early baby boom women in the United States. Demography, 52, 1961-1993.

Glauber R. (2008). Race and gender in families and at work: The fatherhood wage premium. Gender \& Society, 22, 8-30.

Goldin, C. (2004). The long road to the fast track: Career and family. The ANNALS of the American Academy of Political and Social Science, 596, 20-35.

Goldin, C. D., \& Katz, L. F. (2010). The race between education and technology. Harvard University Press.

Hodges, M. J. \& Budig, M. J. (2010). Who gets the daddy bonus? Organizational hegemonic masculinity and the impact of fatherhood on earnings. Gender \& Society, 24, 717-745.

Kalmijn, M., Loeve, A., \& Manting, D. (2007). Income dynamics in couples and the dissolution of marriage and cohabitation. Demography, 44, 159-179.

Keizer, R., \& Schenk, N. (2012). Becoming a parent and relationship satisfaction: A longitudinal dyadic perspective. Journal of Marriage and Family, 74, 759-773

Killewald, A. (2013). A reconsideration of the fatherhood premium: Marriage, residence, biology, and the wages of fathers. American Sociological Review, 78, 96-116.

Killewald, A., \& García-Manglano, J. (2016). Tethered lives: A couple-based perspective on the consequences of parenthood for time use, occupation, and wages. Social Science Research, 60, 266-282.

Killewald, A., \& Gough, M. (2013). Does specialization explain marriage penalties and premiums? American Sociological Review, 78, 477-502.

Light, A. (2004). Gender differences in the marriage and cohabitation income premium. Demography, 41, 263-284.

Lyons, K. S., \& Sayer, A. G. (2005). Longitudinal dyad models in family research. Journal of Marriage and Family, 67, 1048-1060.

Mare, R. D. (1991). Five decades of educational assortative mating. American Sociological Review, 56, 15-32.

Nock, S. L. (2001). The marriages of equally dependent spouses. Journal of Family Issues, 22, 755-775. 
Educational Pairing and Income Dynamics in Couples

Oppenheimer, V. K., Kalmijn, M., \& Lim, N. (1997). Men's career development and marriage timing during a period of rising inequality. Demography, 34, 311-330.

Orloff, A. (1996). Gender and the welfare state. Annual Review of Sociology, 22, 51-78.

Pedulla, D. S. \& Thébaud, S. (2015). Can we finish the revolution? Gender, work-family ideals, and institutional constraint. American Sociological Review, 80, 116-139.

Qian, Y. (2017). Gender asymmetry in educational and income assortative marriage. Journal of Marriage and Family, 79, 318-336.

Qian, Z. (1997). Breaking the racial barriers: Variations in interracial marriage between 1980 and 1990. Demography, 34, 263-276.

Raley, S. B., Mattingly, M. J., \& Bianchi, S. M. (2006). How dual are dual-income couples? Documenting change from 1970 to 2001. Journal of Marriage and Family, 68, 11-28.

Raudenbush, S. W., Brennan, R. T., \& Barnett, R. C. (1995). A multivariate hierarchical model for studying psychological change within married couples. Journal of Family Psychology, 9, 161-174.

Schwartz, C. R. (2010). Earnings inequality and the changing association between spouses' earnings. American Journal of Sociology, 115, 1524-1557.

Schwartz, C. R., \& Han, H. (2014). The reversal of the gender gap in education and trends in marital dissolution. American Sociological Review, 79, 605-629.

Singer, J. D. \& Willett, J. B. (2003). Applied longitudinal data analysis: Modeling change and event occurrence. New York, NY: Oxford University Press.

Stock, J. H. \& Watson, M. W. (2006). Introduction to econometrics (2nd Edition). Prentice Hall.

Sweeney, M. M. (2016). Socioeconomic standing and variability in marriage timing in the twentieth century. The ANNALS of the American Academy of Political and Social Science, 663, 270-291.

Umberson, D., Pudrovska, T., \& Reczek, C. (2010). Parenthood, childlessness, and well- being: A life course perspective. Journal of Marriage and Family, 72, 612-629.

Wang, W. (2014). Record share of wives are more educated than their husbands. http://www.pewresearch.org/fact-tank/2014/02/12/record-share-of-wives-are-moreeducated-than-their-husbands/. Retrieved on 6/10/2017.

Winkler, A. E., McBride, T. D., \& Andrews, C. (2005). Wives who outearn their husbands: A transitory or persistent phenomenon for couples? Demography, 42, 523-535.

Winslow-Bowe, S. (2006). The persistence of wives' income advantage. Journal of Marriage and Family, 68, 824-842.

Winslow-Bowe, S. (2009). Husbands' and wives' relative earnings: Exploring variation by race, human capital, labor supply, and life stage. Journal of Family Issues, 30, 1405-1432. 
Educational Pairing and Income Dynamics in Couples

Table 1. Descriptive Statistics of Time-Invariant (Level-2) and Time-Varying (Level-1) Variables

\begin{tabular}{|c|c|c|c|c|c|c|}
\hline & \multicolumn{3}{|c|}{ Husbands } & \multicolumn{3}{|c|}{ Wives } \\
\hline & $\%$ & Mean & SD & $\%$ & Mean & SD \\
\hline \multicolumn{7}{|l|}{ Level-2 Variables } \\
\hline \multicolumn{7}{|l|}{ Educational assortative mating } \\
\hline Hypergamy (husband more educated than wife) & 22.4 & & & 22.5 & & \\
\hline Homogamy (husband and wife same education) & 53.2 & & & 53.1 & & \\
\hline Hypogamy (wife more educated than husband) & 24.4 & & & 24.4 & & \\
\hline \multicolumn{7}{|l|}{ Education } \\
\hline Less than high school & 17.5 & & & 15.3 & & \\
\hline High school & 43.3 & & & 43.5 & & \\
\hline Some college & 20.2 & & & 22.9 & & \\
\hline College or above & 19.0 & & & 18.3 & & \\
\hline Age at marriage & & 26.1 & 6.0 & & 24.0 & 5.6 \\
\hline \multicolumn{7}{|l|}{ Respondent's race } \\
\hline Hispanic & 19.5 & & & 19.4 & & \\
\hline Black & 22.5 & & & 22.7 & & \\
\hline White & 58.0 & & & 57.9 & & \\
\hline Respondent was wife & 51.9 & & & 52.5 & & \\
\hline \multicolumn{7}{|l|}{ Level-1 Variables } \\
\hline Logged income & & 10.0 & 2.7 & & 7.4 & 4.3 \\
\hline Marital duration & & 7.0 & 5.5 & & 7.0 & 5.5 \\
\hline Number of children & & 1.4 & 1.1 & & 1.4 & 1.2 \\
\hline Hours worked during the year & & $2,150.0$ & 757.2 & & $1,260.0$ & 941.7 \\
\hline
\end{tabular}


Educational Pairing and Income Dynamics in Couples

Table 2. Multilevel Dyad Model Fixed Effects Results and Random Effects Results, Baseline Model (Model 1)

\begin{tabular}{|c|c|c|c|c|c|c|c|}
\hline \multirow{3}{*}{ Model 1} & \multicolumn{6}{|c|}{ Fixed Effects Results } & \multirow{3}{*}{$\frac{\text { Random Effects Results }}{\text { Estimate }}$} \\
\hline & \multicolumn{3}{|c|}{ Husbands } & \multicolumn{3}{|c|}{ Wives } & \\
\hline & $b$ & & SE & $b$ & & SE & \\
\hline Intercept & 9.599 & $* * *$ & 0.032 & 7.839 & $* * *$ & 0.050 & \\
\hline Linear slope: Marital duration & 0.044 & $* * *$ & 0.007 & -0.194 & $* * *$ & 0.008 & \\
\hline Quadratic slope: Marital duration squared & -0.001 & $* * *$ & 0.000 & 0.012 & $* * *$ & 0.000 & \\
\hline \multicolumn{8}{|l|}{ Identity } \\
\hline sd(husbands'/Wives' Quadratic slope) & & & & & & & 0.005 \\
\hline \multicolumn{8}{|l|}{ Unstructured } \\
\hline sd(husbands' intercept) & & & & & & & 1.688 \\
\hline sd(wives' intercept) & & & & & & & 3.430 \\
\hline sd(husbands' linear slope) & & & & & & & 0.074 \\
\hline sd(wives linear slope) & & & & & & & 0.283 \\
\hline corr(husbands' intercept, wives' intercept) & & & & & & & 0.346 \\
\hline corr(husbands' linear slope, wives' linear slope) & & & & & & & 0.043 \\
\hline corr(husbands' intercept, husbands' linear slope) & & & & & & & -0.053 \\
\hline corr(husbands' intercept, wives linear slope) & & & & & & & -0.216 \\
\hline corr(husbands' linear slope, wives' intercept) & & & & & & & -0.125 \\
\hline corr(wives' intercept, wives' linear slope) & & & & & & & -0.439 \\
\hline
\end{tabular}

Note: $\mathrm{SE}=$ Standard Error. $\mathrm{sd}=$ standard deviation, indicating the variance components. corr = correlation, indicating the covariance components. I originally specified the unstructured covariance matrix that allowed for the six variances and fifteen covariances to be distinct. Similar to Keizer and Shenk (2012), because of the very high negative correlation between the linear slope's and quadratic slope's random effects for both husbands (correlation $=-0.91$ ) and wives (correlation $=-0.94$ ), the standard errors of the random effects could not be reliably estimated. Following Keizer and Shenk (2012), I constrained the quadratic random effects to be equal over couples, which resolved convergence issues. This modeling strategy implied that although the quadratic time effects could still be different by gender within couples, the random variation of a husband's and a wife's quadratic time trends in logged income was constrained to be the same over couples.

$* p<.05 ; * * p<.01 ; * * * p<.001$ 
Educational Pairing and Income Dynamics in Couples

Table 3. Multilevel Dyad Model Fixed Effects Results Predicting Husbands' and Wives' Incomes Over Time

\begin{tabular}{|c|c|c|c|c|c|c|c|c|c|c|c|c|}
\hline & \multicolumn{6}{|c|}{ Husbands } & \multicolumn{6}{|c|}{ Wives } \\
\hline & \multicolumn{3}{|c|}{ Model 2} & \multicolumn{3}{|c|}{ Model 3} & \multicolumn{3}{|c|}{ Model 2} & \multicolumn{3}{|c|}{ Model 3} \\
\hline & $b$ & & SE & $b$ & & SE & $b$ & & SE & $b$ & & $\mathrm{SE}$ \\
\hline \multicolumn{13}{|c|}{ Intercept: Income at marriage } \\
\hline Intercept & 9.560 & $* * *$ & 0.055 & 9.489 & $* * *$ & 0.063 & 7.690 & $* * *$ & 0.078 & 9.365 & $* * *$ & 0.060 \\
\hline \multicolumn{13}{|c|}{ Educational assortative mating } \\
\hline \multicolumn{13}{|l|}{ Homogamy (ref.) } \\
\hline Hypergamy & -0.272 & $* *$ & 0.084 & -0.221 & $* *$ & 0.077 & 0.430 & $* * *$ & 0.119 & 0.111 & & 0.073 \\
\hline Hypogamy & 0.114 & & 0.083 & 0.035 & & 0.076 & -0.544 & $* * *$ & 0.115 & -0.112 & & 0.070 \\
\hline \multicolumn{13}{|l|}{ Education } \\
\hline Less than high school & -0.611 & $* * *$ & 0.095 & -0.289 & $* *$ & 0.089 & -3.494 & $* * *$ & 0.139 & -0.974 & $* * *$ & 0.089 \\
\hline \multicolumn{13}{|l|}{ High school (ref.) } \\
\hline Some college & 0.300 & $* * *$ & 0.087 & 0.238 & $* *$ & 0.080 & 1.074 & $* * *$ & 0.117 & 0.303 & $* * *$ & 0.072 \\
\hline College or above & 0.644 & $* * *$ & 0.090 & 0.426 & $* * *$ & 0.086 & 2.499 & $* * *$ & 0.128 & 0.535 & $* * *$ & 0.082 \\
\hline Age at marriage & & & & 0.002 & & 0.005 & & & & -0.035 & $* * *$ & 0.006 \\
\hline Respondent was wife & & & & -0.247 & $* * *$ & 0.058 & & & & 0.005 & & 0.055 \\
\hline \multicolumn{13}{|l|}{ Respondent's race } \\
\hline Hispanic & & & & 0.024 & & 0.078 & & & & -0.346 & $* * *$ & 0.074 \\
\hline Black & & & & -0.270 & $* * *$ & 0.076 & & & & -0.147 & $*$ & 0.072 \\
\hline White (ref.) & & & & & & & & & & & & \\
\hline
\end{tabular}

Continued 
Educational Pairing and Income Dynamics in Couples

Table 3 continued

\begin{tabular}{|c|c|c|c|c|c|c|c|c|c|c|c|c|}
\hline & \multicolumn{6}{|c|}{ Husbands } & \multicolumn{6}{|c|}{ Wives } \\
\hline & \multicolumn{3}{|c|}{ Model 2} & \multicolumn{3}{|c|}{ Model 3} & \multicolumn{3}{|c|}{ Model 2} & \multicolumn{3}{|c|}{ Model 3} \\
\hline & $b$ & & SE & $b$ & & SE & $b$ & & SE & $b$ & & SE \\
\hline \multicolumn{13}{|l|}{ Linear: Marital duration } \\
\hline Intercept & 0.021 & & 0.012 & -0.005 & & 0.014 & -0.212 & $* * *$ & 0.014 & -0.077 & $* * *$ & 0.014 \\
\hline \multicolumn{2}{|l|}{ Homogamy (ref.) } & & & & & & & & & & & \\
\hline Hypergamy & 0.010 & & 0.019 & 0.022 & & 0.016 & -0.067 & $* *$ & 0.021 & 0.000 & & 0.016 \\
\hline Hypogamy & 0.009 & & 0.018 & 0.026 & & 0.016 & 0.186 & $* * *$ & 0.021 & 0.041 & $* *$ & 0.016 \\
\hline \multicolumn{13}{|l|}{ Education } \\
\hline \multicolumn{13}{|l|}{ High school (ref.) } \\
\hline Some college & 0.016 & & 0.019 & 0.004 & & 0.017 & -0.052 & $*$ & 0.021 & -0.011 & & 0.016 \\
\hline College or above & 0.072 & $* * *$ & 0.019 & 0.063 & $* * *$ & 0.018 & -0.187 & $* * *$ & 0.022 & 0.020 & & 0.018 \\
\hline Age at marriage & & & & -0.005 & $* * *$ & 0.001 & & & & 0.006 & $* * *$ & 0.001 \\
\hline Respondent was wife & & & & 0.018 & & 0.012 & & & & 0.009 & & 0.012 \\
\hline \multicolumn{13}{|l|}{ Respondent's race } \\
\hline Hispanic & & & & -0.006 & & 0.016 & & & & 0.044 & $* *$ & 0.016 \\
\hline Black & & & & -0.026 & & 0.017 & & & & 0.050 & $* *$ & 0.017 \\
\hline White (ref.) & & & & & & & & & & & & \\
\hline
\end{tabular}

Continued 
Table 3 continued

\begin{tabular}{|c|c|c|c|c|c|c|c|c|c|c|c|c|}
\hline & \multicolumn{6}{|c|}{ Husbands } & \multicolumn{6}{|c|}{ Wives } \\
\hline & \multicolumn{3}{|c|}{ Model 2} & \multicolumn{3}{|c|}{ Model 3} & \multicolumn{3}{|c|}{ Model 2} & \multicolumn{3}{|c|}{ Model 3} \\
\hline & $b$ & & SE & $b$ & & SE & $b$ & & $\mathrm{SE}$ & $b$ & & SE \\
\hline \multicolumn{13}{|c|}{ Quadratic: Marital duration squared } \\
\hline Intercept & -0.001 & & 0.001 & 0.000 & & 0.001 & 0.013 & $* * *$ & 0.001 & 0.005 & $* * *$ & 0.001 \\
\hline \multicolumn{13}{|l|}{ Educational assortative mating } \\
\hline \multicolumn{13}{|l|}{ Homogamy (ref.) } \\
\hline Hypergamy & -0.000 & & 0.001 & -0.001 & & 0.001 & 0.002 & & 0.001 & -0.000 & & 0.001 \\
\hline Hypogamy & -0.000 & & 0.001 & -0.001 & & 0.001 & -0.007 & $* * *$ & 0.001 & -0.002 & * & 0.001 \\
\hline \multicolumn{13}{|l|}{ Education } \\
\hline Less than high school & -0.001 & & 0.001 & -0.000 & & 0.001 & -0.008 & $* * *$ & 0.001 & -0.002 & $*$ & 0.001 \\
\hline \multicolumn{13}{|l|}{ High school (ref.) } \\
\hline Some college & 0.000 & & 0.001 & 0.001 & & 0.001 & 0.001 & & 0.001 & 0.001 & & 0.001 \\
\hline College or above & -0.002 & $*$ & 0.001 & -0.002 & & 0.001 & 0.004 & $* * *$ & 0.001 & -0.001 & & 0.001 \\
\hline Age at marriage & & & & 0.000 & & 0.000 & & & & -0.000 & $* * *$ & 0.000 \\
\hline Respondent was wife & & & & -0.001 & & 0.001 & & & & -0.001 & & 0.001 \\
\hline \multicolumn{13}{|l|}{ Respondent's race } \\
\hline Hispanic & & & & 0.000 & & 0.001 & & & & -0.001 & & 0.001 \\
\hline Black & & & & 0.001 & & 0.001 & & & & -0.004 & $* * *$ & 0.001 \\
\hline \multicolumn{13}{|l|}{ White (ref.) } \\
\hline Number of children & & & & -0.039 & $*$ & 0.017 & & & & -0.235 & $* * *$ & 0.017 \\
\hline Hours worked during the year & & & & 0.001 & $* * *$ & 0.000 & & & & 0.003 & $* * *$ & 0.000 \\
\hline
\end{tabular}

Note: Homogamy refers to marriages in which the husband and the wife have same levels of education. Hypergamy refers to marriages in which the husband has more education than the wife. Hypogamy refers to marriages in which the wife has more education than the husband.

Number of children was negatively associated with husbands' income $(b=-0.039, p<0.05)$. This result, however, did not contradict prior findings of a fatherhood wage premium (Glauber, 2008; Hodges \& Budig, 2010; Killewald, 2013). By decomposing this time-varying number of children into a time-invariant average value and the time-varying deviations from that average (indicating the association between husbands' income and the relative number of children at each point in time in comparison to the average at the individual level; Singer \& Willett, 2003), I found that lower-income husbands tended to have a larger family size but increases in the number of children did not hurt husbands' income.

$* p<.05 ; * * p<.01 ; * * * p<.001$ 
Figure 1. Predicted AVERAge Income Trajectories for Husbands AND Wives OVER the MARITAL LIFE COURSE

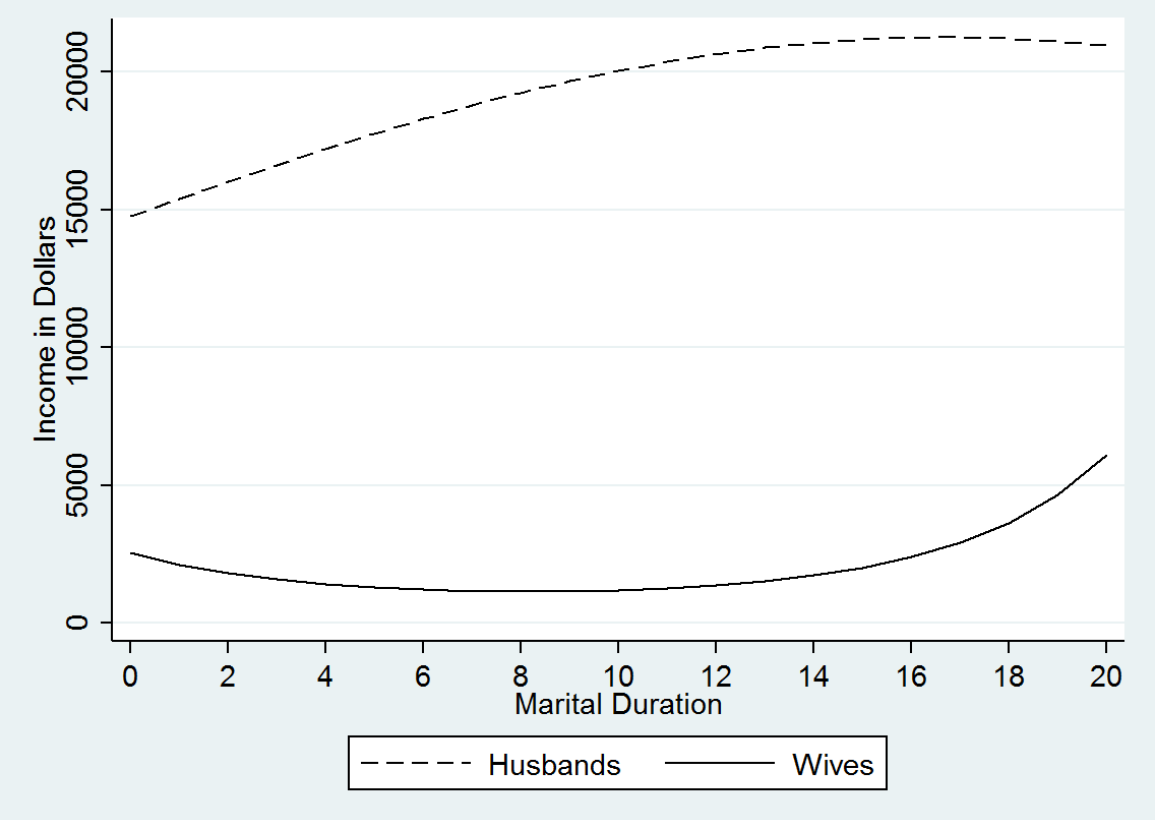

Figure 2. Predicted AVERAge Income Trajectories FOR HuSbands AND Wives OVER the MARital Life Course, By EdUCATIONAL AsSortative MATING
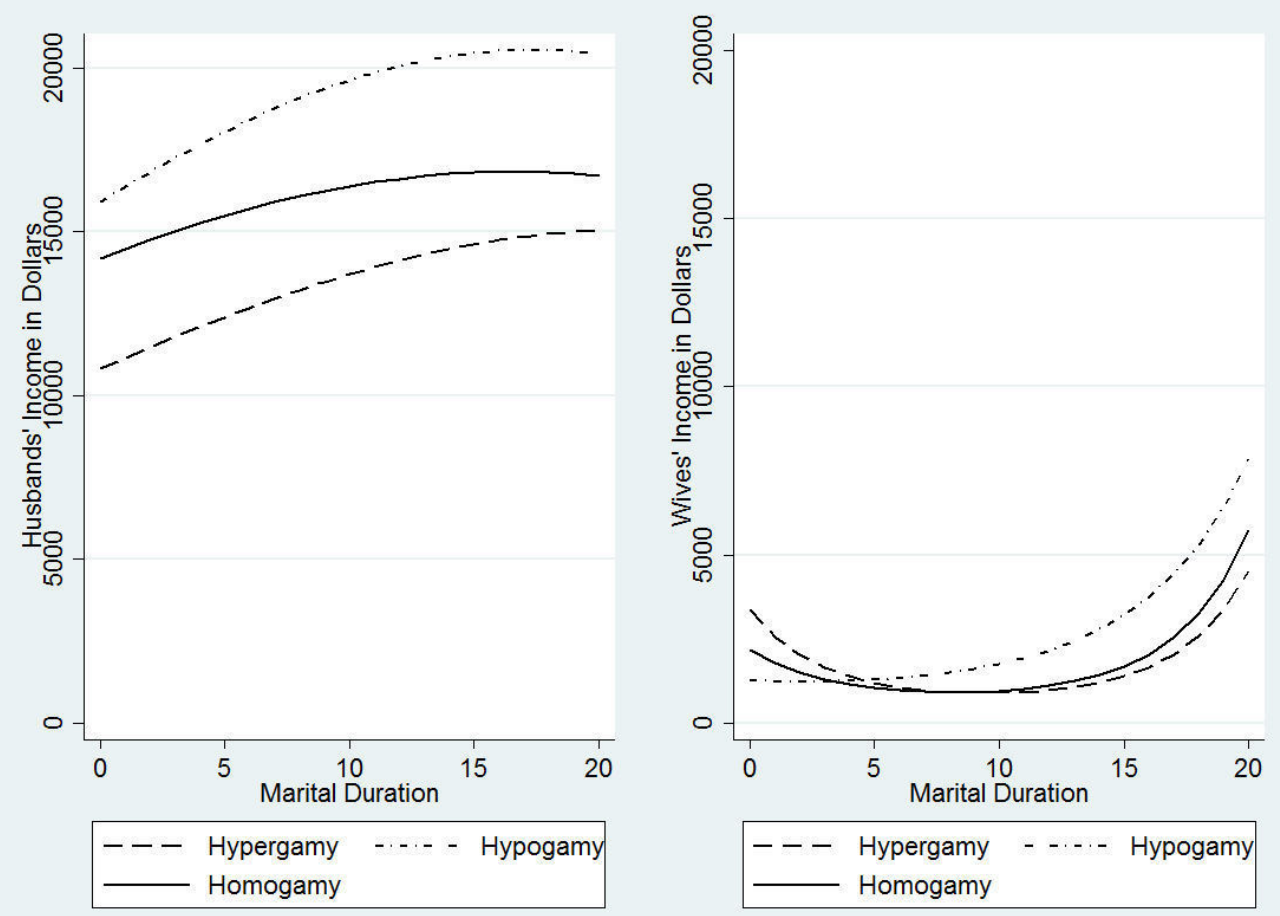

Note: Hypergamy refers to marriages in which the husband has more education than the wife. Hypogamy refers to marriages in which the wife has more education than the husband. Homogamy refers to marriages in which the husband and the wife have same levels of education. 